arise now that the microscope is at hand. Nevertheless, favus and impetigo are confounded with lepra, eczema, and tinea tonsurans, notwithstanding the cupped-crust favi of the former and the dry nibbled patches of the latter, in which the epithelial cells and hairs are literally eaten away by the fungus, when this is in abundance. Chloasma, with its itching and desquamation, is very frequently indeed mistaken for syphilitic maculæ. Sycosis is often non-parasitic; in this case, the damaged split-up hairs will be absent, whilst the disease travels up into the whiskers.

There are three agencies that need a special word of comment-the use of flannel, scratching, and gravitation; but these must be reserved for another occasion. The condensed sketch I have given may help the student in the out-patient's room and the practitioner in his busy practice, and pave the way for some remarks on individual diseases.

Sackville-street, Feb. 1867.

\section{ON ABNORMAL CONDITIONS OF THE DIAPHRAGM.}

BY F. HOWARD MARSH, F.R.C.S.

Physicians and pathologists are alike indebted to Mr. Callender for his paper on "Fatty Degeneration of the Diaphragm," which appeared in THE LANCET of January 12th. His cases prove that the disease, which, though no doubt known to some observers, had not been well described, can be by no means very rare; and they point out what is really the cause of death in certain obscure cases which have hitherto been reckoned as instances of heart disease. The following case, which Mr. Paget has kindly given me leave to publish, may stand as a supplement to those of Mr. Callender. It is not exactly like his, for the diaphragm was not altered by fatty degeneration, but was, as Mr. Paget believed, defective in its original development; but the patient's symptoms, and the manner of his death, were very similar to those noted by Mr. Callender; and the case serves to keep attention fixed on the very important fact that the diaphragm may, either by congenital defect, or, much more commonly, through subsequent disease, so fail in its action as to lead, sooner or later, to rapid death.

On September 20th, 1851, Mr. Archer, who was then housesurgeon, admitted into St. Bartholomew's Hospital a man who said that just before his master was going to strike him, and in a fright, he jumped back, and felt something "give way" in his chest. He was faint and depressed, and it was thought he might have burst an aneurism. He complained also of pain in the left side of his chest, but his symptoms were obscure, and he was left to rest. In the evening he had dyspnoea, and a cough, which he had before, was aggravated. He was found next day to have double pneumonia, and with this, and with increasing dyspnœa, two davs later he died.

In the examination aiter death Mr. Paget found that the greater part of the lower lobe of the right lung, and the lower half of the upper lobe of the left lung, were completely solidin well-marked red hepatisation. Obsolete tubercles existed in the upper part of the right lung, but, with these exceptions, his organs appeared of normal structure. The condition of the diaphragm, however, was remarkable. Its left half was arched up to the third intercostal space, and the stomach, which was extremely large, was pushed up so high as to be nearly concealed by the left ribs; the liver lying below, and in front of it. The right side of the diaphragm appeared normal. On closer examination, the left side of the diaphragm was seen to be almost wholly wanting in muscular fibres. In the left crus, which was about half as large as natural, there were bundles of pale, muscular fibres, but in the rest of the left side there were only just so many of these that, on holding the diaphragm to the light, a few pale, pinkish lines could be seen radiating from its central tendon to its outer border. These were just visible enough for saying that muscular fibres were not wholly wanting. On the right side all appeared normal. No defect of symmetry was found either among the intercostal muscles or in any other part.

Mr. Paget remarks in a note on the case that the defect of the diaphragm was probably a congenital one, for there was no apparent abnormality of structure; the pleura and peritoneum lay in contact, but were healthy in texture, and with no fat or other degenerate substance between them. And he adds: "There appeared, notwithstanding this defect, to be sufficient respiratory power. The patient breathed very forcibly in his dyspnoa, and in auscultating him the move. ments of the chest appeared just as in an ordinary double pneumonia. The stomach was thought to be, as it was found, very high up, but nothing unusual attracted Mr. Archer's or my attention; the left side of the chest certainly moved freely, and the patient often lay on his right side."

St. Bartholomew's Hospital, Jan. 1837.

\section{d. afthrox}

OF THE PRACTICE OF

\section{MEDICINE AND SURGERY}

IN THE

\section{HOSPITALS OF LONDON.}

Nulla autem est alia pro certo noscendi via, nisi quamplurimas et morborum et dissectionum historias, tum aliorum, tum proprias collectas habere, et inter se comparare.-Morgagni De Sed. et Caus. Morb., lib. iv. Procmium.

\section{MIDDLESEX HOSPITAL.}

\section{A CASE IN WHICH A COMMON SEWING-NEEDLE CAUSED}

$$
\begin{gathered}
\text { DEATH BY HAMORRHAGE FROM THE AORTA } \\
\text { INTO'THE PERTCARDIUM. }
\end{gathered}
$$

AN inquest was held on the 16th ult. on the body of a woman named Maria Thompson, aged forty, who died under the following very remarkable circumstances:-

It appears that the deceased, who was a woman of intem. perate habits, went to bed on the night of the 11th apparently in good health. At three o'clock on the following morning, however, a female who slept in the bed with deceased was awakened by hearing her make a peculiar "groaning noise," though at the same time she was quite unconscious. She was aroused, and after being taken out of bed and having a cup of tea she revived. A short time afterwards she became faint, and was seized with diarrhoa and vomiting; and remained very much in this condition, sometimes being a little better and then again becoming worse, until about a quarter to ten A.M., when she was brought to the hospital in a cab. She was immediately admitted, and seen by Mr. A. Waymouth, the resident medical officer, who at once pronounced her to be dead. Death had taken place whilst she was being conveyed to the hospital. Mr. Waymouth has obliged us with notes.

At the post-mortem examination, the pericardium, on being opened, was found to be full of blood-clots; and on the hand of the operator being introduced into its cavity, the forefinger was pricked by some foreign body, which was removed. It proved to be a sewing-needle, without an eye, in a very blackened and roughened state, and about two inches in length. From its appearance, it had probably been in the body for a considerable time. On the heart and great vessels being examined, three spots of ecchymosis, each about the size of a threepenny-piece, were found on the anterior wall of the ascending portion of the arch of the aorta; and on that vessel being opened, two puncturos were found on its inner surface, corresponding with two of the spots of ecchymosis. These were situated, one about a quarter and the other about threequarters of an inch above the aortic valves; so that the point of the needle had evidently passed through the coats of the artery about a quarter of an inch above the semilunar valves, had passed out again about a quarter of an inch higher up, and had finally lodged itself in the outer coat of the artery near that part where the left carotid is given off, being just within the reflection of the pericardium.

The points are indicated in the accompanying rough diagram which we sketched from the preparation. At 1 the needle had apparently first pierced the aorta, emerging at 2 , to bury itself again in the coats of the vessel at 3 . Just above this last the reflection of the pericardium is meant to be represented.

Death in this instance had doubtless been caused by the heart's action being arrested, consequent on the pericardium having become full of blood from the gradual oozing which had taken place from the punctures in the aorta. How came the needle in this position? It must, it would appear, have been by one of two modes : it must have been swallowed, or have been 